\title{
Poética de la imagen de perfil
}

\author{
Profile picture poetics
}

\author{
JOSÉ LUIS MOLINUEVO \\ Universidad de Salamanca (España)
}

Recibido: 11-XII-2015 Aceptado: 17-XII-2015

\begin{abstract}
RESUMEN
Estas páginas se dedican a indagar en ciertos aspectos de la filmografía de Christian Petzold, uno de los directores más signicativos del nuevo cine alemán, posterior a la caída del muro de Berlín. Tomando como clave hermenéutica la presencia en estas películas de «la imagen de perfil», se toma el pulso a la actualidad del efecto de distanciamiento propuesto por Brecht, los nuevos recursos empleados en la técnica de «montaje suave» (Farocki) y la voluntad de Petzold de documentar la verdad a través de la ficción. El tratamiento insistente, a través de la imagen cinematográfica, de los traumas sufridos por las dos Alemanias a lo largo del siglo XX constituye el argumento principal de este artículo.
\end{abstract}

\section{PALABRAS CLAVE}

CINE ALEMÁN, PETZOLD, DISTANCIAMIENTO, IDENTIDAD, MONTAJE

\section{ABSTRACT}

These pages are dedicated to investigate certain aspects of the filmography of Christian Petzold, one of the most significant directors of the new German cinema, after the fall of the Berlin Wall. Taking as an hermeneutical key the presence of "the profil picture" in these films, the pulse is taken of the effect's actuality of the distancing propoed by Brecht, the new resources employed in the art of «soft editing» (Farocki) and the determination of Petzold to document the truth trough fiction. The insistent tratment, trough the filmic image, of the traumas suffered by the two Germanys during the twentieth century is the main argument of this article.

KEYWORDS

GERMAN CINEMA, PETZOLD, DISTANCING, IDENTITY, MOUNTING

(C) Contrastes. Revista Internacional de Filosofia, vol. XXI-No3 (2016), pp. 219-239. ISSN: 1136-4076 Departamento de Filosofía, Universidad de Málaga, Facultad de Filosofía y Letras

Campus de Teatinos, E-29071 Málaga (España) 


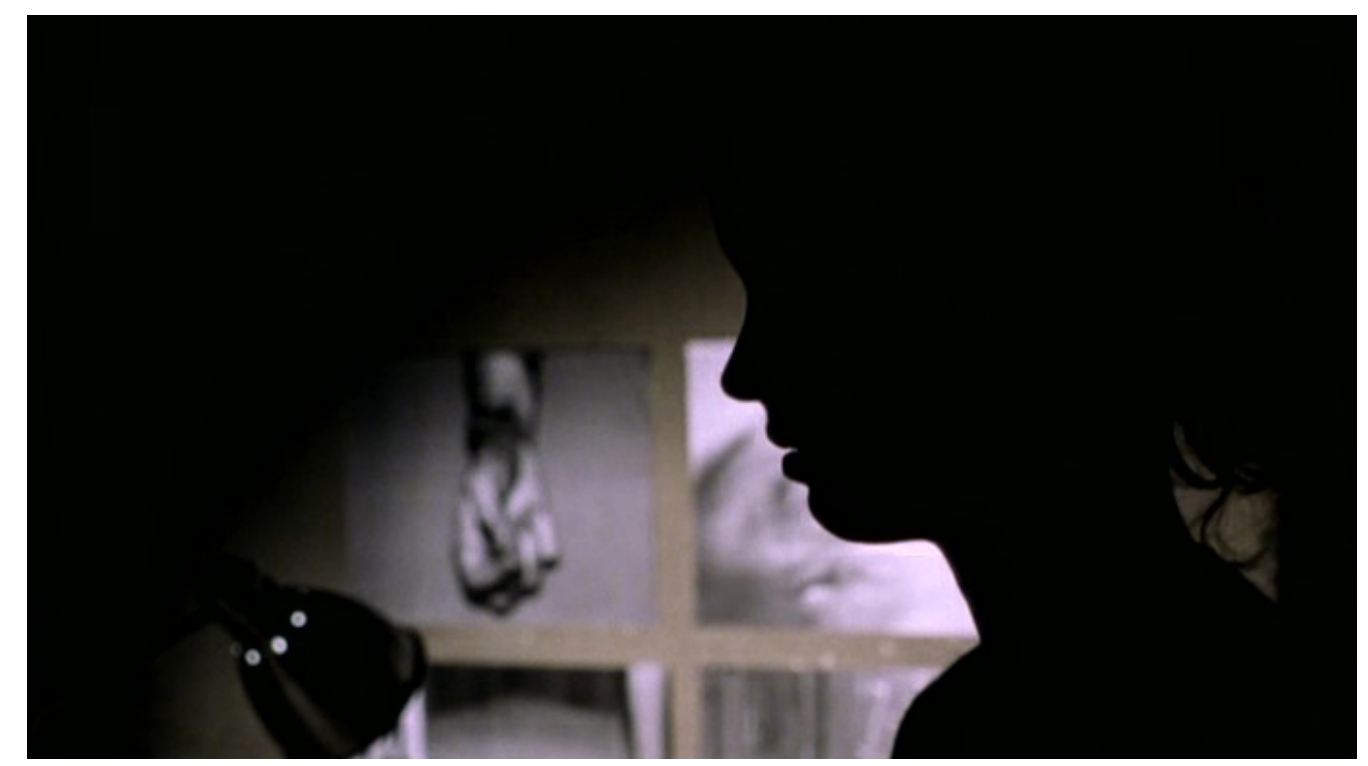

Fig. 1

A RIESGO DE INCURRIR EN UNA HEREJÍA CULTURAL se puede aventurar un cierto paralelismo entre el denominado «fin del (Gran) Arte» atribuido a Hegel a comienzos del siglo XIX y el diagnóstico de Susan Sontag sobre el «fin del (Gran) Cine» a finales del siglo XX. En la intersección de ambos Heidegger precisa en su meditación sobre el final de la filosofía y la tarea del pensar que la palabra fin no es un final como cese de algo sino todo lo contrario, una finalidad, el momento en que se concentran todas las fuerzas creativas de la filosofía para dar el gran salto a lo que constituye su gran objetivo pendiente: la tarea de pensar volviendo a sus orígenes. Es sabido que, con raras excepciones, para la generación de 1914 esta no pasa, sino todo lo contrario, por la imagen. Por el Arte sí, por las (otras) imágenes no.

Para Sontag lo más valioso del cine como arte era la cinefilia, la vida en, por, y para el cine, el cine como obra de arte total que impregnaba la existencia. Éste había sido el distintivo de las «nuevas olas», empezando por la matricial de todas, la francesa. El objetivo de este ensayo no es tanto mostrar que no ha muerto el cine (está más vivo que nunca aunque ya casi no se vea, en las salas, y sí más bien en los museos, los ordenadores y en el Smartphone), sino que sigue siendo una oportunidad, entre otras muchas, de pensar en imágenes, algo muy interesante para la estética. Este «nuevo» cine concentra las energías icónicas de los anteriores y entiende la «novedad» como el deseo de satisfacer una necesidad antigua volviendo a sus orígenes. Si en La mirada de Ulises (1995) de Angelopoulos, el director en crisis existencial y creativa volvía sus ojos a los balbuceos del cine griego, como si de los presocráticos se tratara, ahora las referencias a la primera película de la historia del cine, La Sortie de 
l'usine Lumière à Lyon (1895), se multiplican buscando las raíces de su nuevo espíritu, el trabajo, y la forma: la mezcla de ficción y documental.

Ya que este es un ensayo de estética se impone la concreción y la referencia a unas determinadas imágenes, no para demostrar una tesis previa, sino para mostrar de dónde han salido las reflexiones que se vierten: se trata en su mayoría de la (nueva) Escuela de Berlín, su contexto estilístico y, más en concreto, de la obra del director Christian Petzold. Dado que, como suele ocurrir, rechazan ser una escuela y no todos son de Berlín, habrá que recurrir a algunos rasgos estilísticos comunes para mantener, aunque sea mínimamente, la caracterización. Uno de ellos es que se trata de un cine llamado «postmuro» de Berlín, en el que la mirada vuelve sobre el pasado alemán (el nazismo, la reunificación, el terrorismo, la inmigración) desde los vacíos creados en el presente por el capitalismo tardío. Avanzamos que, además de la mezcla de cine documental y ficción, a las poéticas anteriores de identificación prefieren ahora las de extrañamiento. El «montaje suave» (Farocki) propicia que lo pretendido en la abrupta técnica del extrañamiento heredada de Brecht se logre ahora en esas imágenes tristes resultado de una poética de imágenes de perfil [fig. 1]. Es el nuevo realismo.

Se trata, efectivamente, de un Brecht pasado por Godard, gran admirador suyo: «Porque es necesario no olvidar que el cine debe, hoy más que nunca, conservar como regla de conducta este pensamiento de Bertolt Brecht: "El realismo no es como son las cosas verdaderas, sino como son verdaderamente las cosas". Cabría añadir que esa es una de las diferencias fundamentales entre el realismo en filosofía y en el cine y la meta de pensar con el cine».

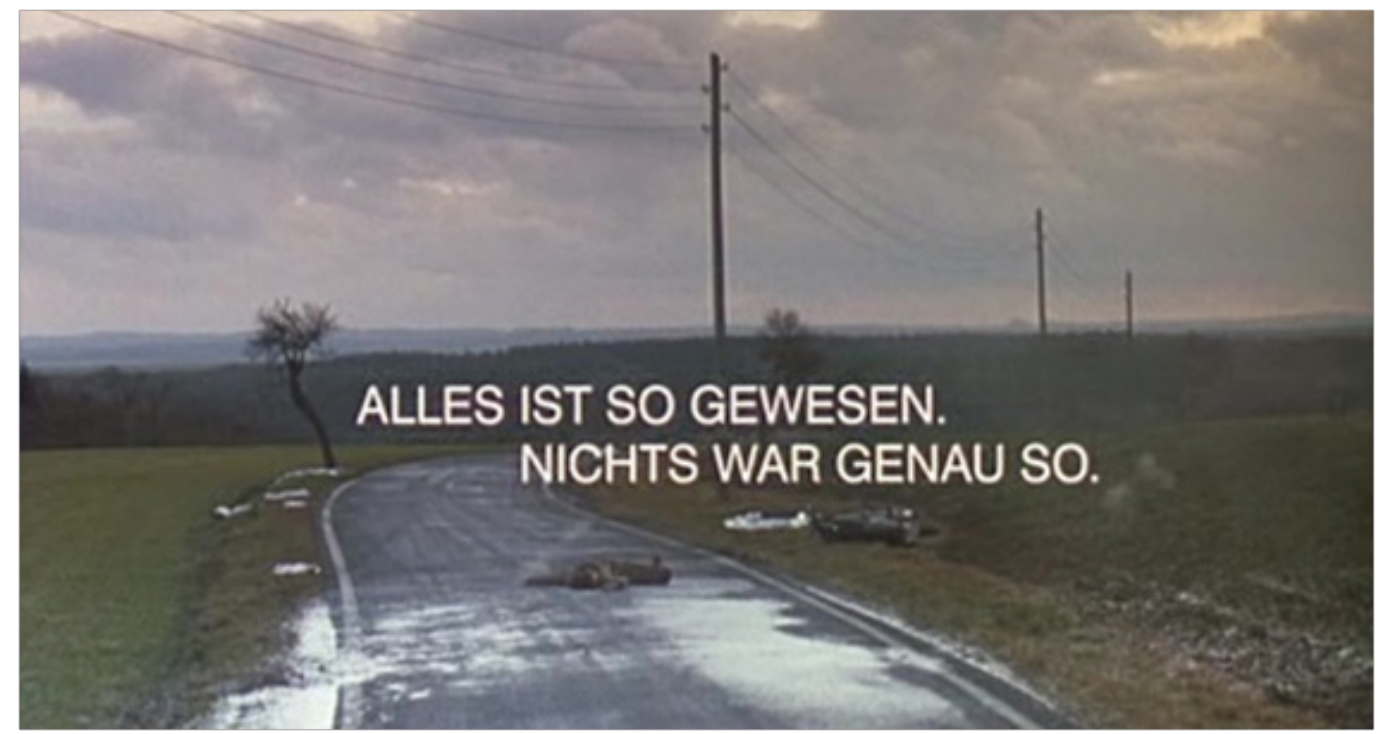

Fig. 2 
Al final de la película de Volker Schlöndorf Die Stille nach dem Schuss (2000) aparece sobreimpuesta la siguiente leyenda: «Alles ist so gewesen. Nichts war genau so» (Todo ha sucedido así, pero nada fue exactamente así) [fig. 2]. Un ligero picado muestra con el plano general de una tarde lluviosa y triste el cuerpo inerte de Rita Vogt, cruzado en una carretera secundaria, después de recibir una ráfaga del policía de fronteras. Es el final de una huida de la antigua terrorista a través de diferentes identidades por las que solo quiere conseguir lo que todos, una vida normal. Se inscribe, como veremos, en todo un movimiento de cine en Alemania que aspira a documentar la verdad de las cosas a través de la ficción, no las cosas verdaderas desde la exactitud ¿Cuál es la diferencia? El elemento común y, a la vez, distintivo de estas películas es lo que llamaremos «el factor humano». Cuando Herzog entrevista y filma a los condenados en el corredor de la muerte introduce una distinción polémica: no hay seres humanos malos, sino seres humanos que hacen cosas malas. Lo primero, la maldad, no se puede filmar, todo lo más perderse en una serie de divagaciones metafísicas; un ser humano que ha hecho cosas malas propicia una narración interminable llena de matices, un caleidoscopio de diferentes miradas. Y esto es lo que lleva a cabo Petzold en su película Toter Mann (2001), donde el asesino y violador Blum (un monstruo del Frankenstein social) cree percibir en el increíble interés de Leyla hacia su persona una segunda oportunidad que le da la vida para la reinserción. Cree, y el antiguo espectador también, a pesar de la distancia introducida en la narración.

Este efecto de distanciamiento en aras a la fidelidad, que no a la verosimilitud, de lo real plantea interesantes preguntas hermenéuticas en cuanto al montaje: ¿Por qué no simplemente, como recomendaba Adorno, asumir como modelo en el cine el montaje de la escritura? En Etwas wird sichtbar (1981), de Farocki, el soldado Tanner dice a una mujer del Vietcong que realmente ya no es un soldado sino más bien un filósofo. Y ella pregunta «¿qué clase de filosofía?». Tanner responde: «la filosofía pregunta ¿qué es el hombre?, yo pregunto ¿qué es una imagen? En nuestra cultura las imágenes tienen poca importancia. Se las trata como criadas. Se pregunta a las imágenes para obtener informaciones y solo las informaciones que pueden expresarse en palabras y números». Tanner afirma que es un filósofo, pero parece interesarse, preguntar, por cosas distintas que la filosofía ¿O son las mismas? ¿Acaso no es la nueva forma de preguntar por el hombre pero en imágenes?

Pero para eso es preciso salir de lo binario. En 1975 Farocki coescribe con Bitomsky una película Auf Biegen oder Brechen en cuya presentación a la prensa se adjunta un texto de Bitomsky titulado «Algo sobre la relación entre ficción y realidad»: 
He leído en Bazin que hay el director de cine que cree en la IMAGEN y el director de cine que cree en la REALIDAD. En medio no hay nada.

Esa frase me ha impresionado e inquietado porque sigue confirmando la vieja separación.

Uno puede como intelectual enfrentarse al mundo como comentarista, analista que muestra una imagen (copia) del mundo; o como persona que cita, observa, pero que lo deja como está.

Yo siempre he querido las dos cosas: la realidad y la imagen, lo concreto y la idea, el hecho y la imaginación, lo encontrado y lo inventado.

En el breve texto se habla de dos modelos de director de cine, y se equipara al que cree en la imagen (del mundo) con el intelectual que hace lo mismo cuando piensa o emplea imágenes como copia del mismo, dejándolo tal cual está. El otro director de cine está situado en el intermedio de esos modelos y quiere la imagen y la realidad. La imagen ya no es copia, la realidad no es la realidad abstracta, esencial. Lo llamativo en ese planteamiento es que el partidario de la teoría crítica habría querido justamente situarse en este modelo de director de cine porque hace lo que le gustaría hacer, pero no hace como teórico: reunir, a la vez, lo concreto y la idea. Y eso es lo que obtiene como resultado, no un proceso de abstracción, sino el montaje, las nuevas técnicas de montaje posibilitadas por las nuevas tecnologías de lo audiovisual. Se va a producir así una brecha entre un tipo de cine de los años sesenta, militante, de denuncia, simbólico, con la vocación pedagógica tomada de Brecht, a otro cine de imagen y realidad en el que predominará otro mecanismo, originario también de Brecht, como es el de extrañamiento.

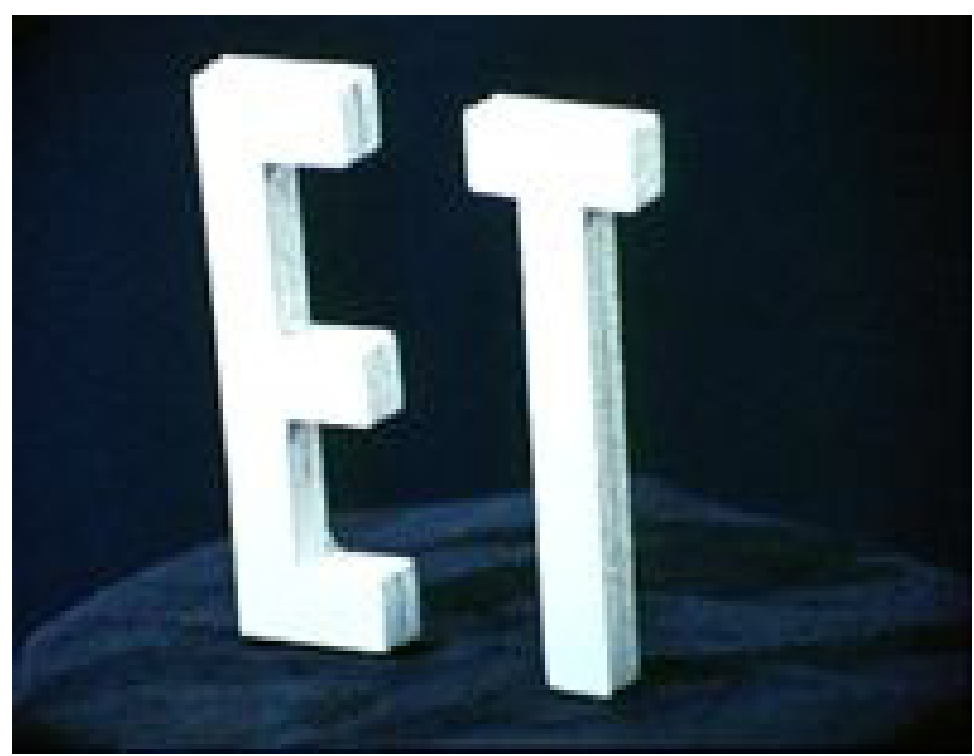

Fig. 3 
Es un cine de percepción. El enfoque cambia pero las imágenes siguen apareciendo, se repiten, en un loop incansable. Porque, lo adelantamos, no es un cine que avanza ya solo con negaciones, disyuntivo, sino también con afirmaciones, conjuntivo. Frente al manifiesto de los intelectuales y cine $O$, es el cine $Y$. Se trata de un camino intermedio, y el problema de esos caminos es que no llaman la atención hasta que llevan un largo recorrido. Ese otro momento, de la segunda mitad de los años setenta, supone una revisión de las prácticas de los sesenta. Esta imagen de Aqui y allá (1976) de Godard lo resume gráficamente [fig.3].

Godard en Numéro deux (1975) explica que el cine es sucesión mientras que el vídeo simultaneidad; el primero excluye (después de una imagen viene otra), el segundo incluye (una imagen junto a otra). El primero sería $O$, el segundo $Y$, disyuntivo y conjuntivo, respectivamente. Pero hay otros elementos que, en forma de motivos o reflexión, van a ser una constante en su obra. Uno de ellos, el que Godard señala al comienzo: el cine es una fábrica de imágenes. Es decir, que el motivo de la fábrica, desde su homenaje a la primera película en que salen los trabajadores de la fábrica de productos fotográficos, va ser constante, en diferentes contextos en su obra. Es una fábrica, taller, en la que se trabaja con imágenes. Godard muestra su lugar de trabajo, como signo del cambio. Godard pretende renunciar al cine de auteur para introducir ese yo trabajador que es lo contrario de la autoficción y que muestra, más que las imágenes producidas, las halladas. El cine como trabajo es básicamente montaje. De ese modo se diluyen también las fronteras entre el documental y la ficción.

En cierto modo el último nuevo cine alemán responde a aquella necesidad expresada en los años 70 de pasar de un cine de ideas a un cine de personas. Era lógico, pues las ideas no existen en sí, sino las personas que tienen ideas, cualesquiera que sean. Era lógico, pero es entonces cuando empiezan los problemas, la nueva relación del planteamiento estético con el ético y el político tradicionales. En 2005 El Hundimiento de Olivier Hirschbiegel supone un cierto escándalo ya que muestra a un Hitler alejado de los estereotipos: en su desvalimiento, su bondad inesperada, su locura asesina. Todo ello mezclado sin una lógica aparente. El águila nazi tiene Parkinson y no puede sujetar el mundo con sus garras, apenas reprimir un momento el temblor de la mano, todo se le escapa y los alaridos de antaño son ahora roncos gemidos de impotencia, magistralmente encarnados por un Bruno Ganz, actor icono del cine de izquierdas. No es un cine de conceptos y el untergehen no tiene el glamour wagneriano, el decadentismo viscontiano, ni tampoco el cinismo distante del «Gran Hotel Abismo» luckasiano. La identidad del concepto deja paso a la complejidad de la imagen en los personajes sujetos a pulsiones contradictorias ¿A qué obedece este cambio en el modo de volver a la historia? 
La respuesta no es difícil y va en la misma línea de que toda historia para la vida es historia contemporánea, según avanzara Nietzsche. Lo que ha cambiado es el presente, las «cosas», en terminología passoliniana. Y eso hace que temas como el Holocausto, la Stasi, el terrorismo, la inmigración, las víctimas de todo tipo, se crucen con la percepción de la historia y de la vida cotidiana por parte de quienes, en algunos casos, no tienen una identidad que los respalde. En palabras del director Thomas Arslan se trata de mostrar sin juzgar, recogiendo el cambio que propugnara Godard entre hacer una película política y hacer políticamente una película.

La poética de la imagen de perfil es una poética del extrañamiento. Se entiende mejor si se contrapone a la teoría de la identificación de Metz que goza de un cierto predicamento. No se trata ni de la identificación primaria, la ilusión de realidad de la imagen, ni secundaria, la identificación con los personajes. Petzold afirma con toda rotundidad en una entrevista de Marco Abel: «el cine de identificación me pone de los nervios». En la imagen de perfil es imposible identificar la realidad e identificarse con los personajes, ya que el perfil introduce una distancia insalvable. Y eso hace que sean películas en las que el antiguo espectador es sustituido por el trabajador. Este es un cine trabajo. En la imagen de perfil la persona aparece situada entre dos espacios, dos tiempos, en la ambigüedad de lo «real» y lo alucinatorio. No tiene una identidad sino que aparece ambigua, compleja, escindida, contradictoria en suma, es decir, llena de matices y de posibilidades.

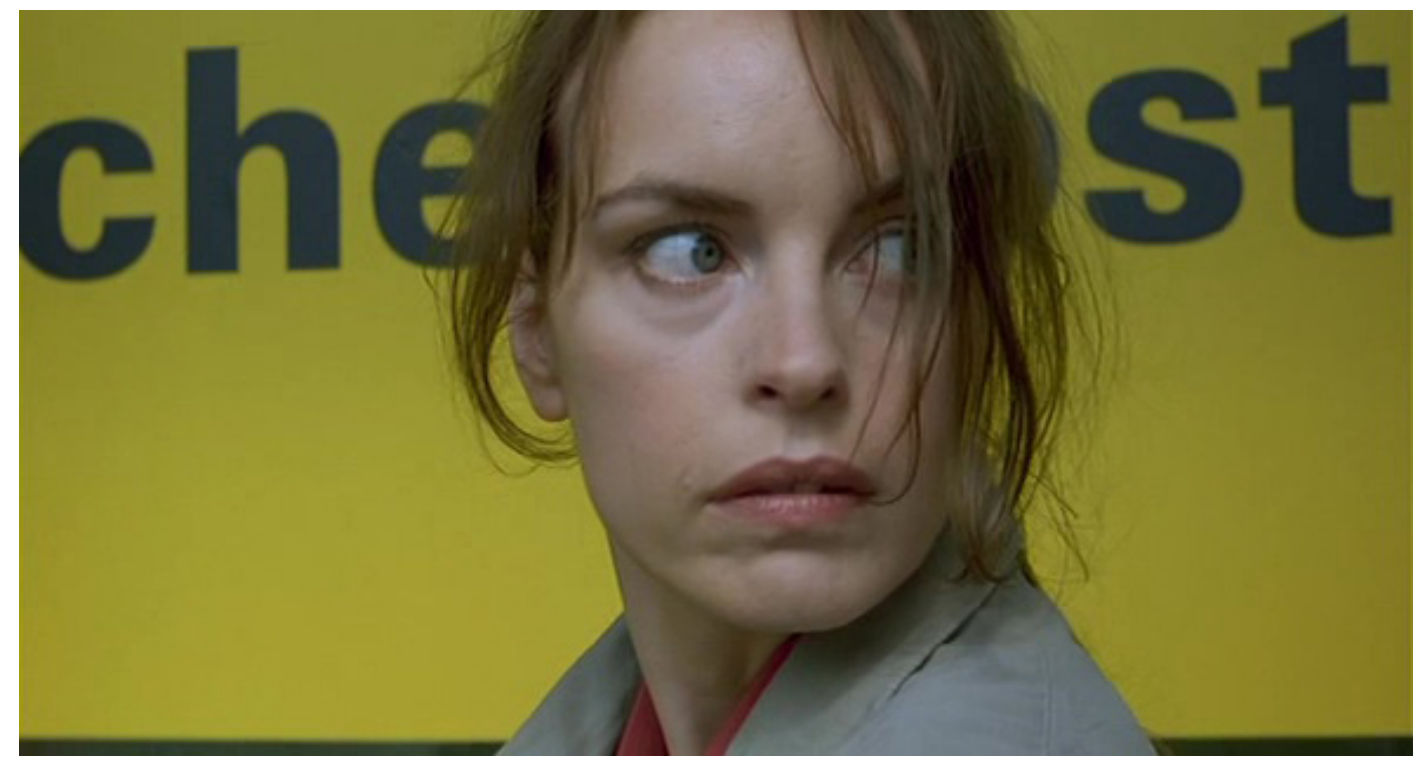

Fig. 4 
Son seres intermedios que habitan lugares intermedios, espacios de tránsito antes llamados no lugares, automóviles en los que el plano y contraplano arroja dos perfiles de los pasajeros, que no viajeros, andares sin fin y sin rumbo en la calle, filmados caminando de espaldas a la cámara o desde un travelling lateral. Quizá sea esta la palabra que une todo en la generación de la imagen de perfil: travelling. Se trata de una movilidad inmóvil, los personajes se mueven sin cesar pero no progresan, como si de hámsters existenciales se tratara. Quieren ser normales, tener una casa, una familia, pero hay siempre un elemento social, histórico, político, en perpetuo fuera de campo que condiciona todo. A diferencia de los hombres errantes de Nicholas Ray, no es que no puedan volver a casa ni que no haya ninguna casa a la que volver (solo las cuatro tablas de la casa añorada y en ruinas), sino que no pueden pararse aunque lo intentan. Además, en algunos casos con riesgo de vencimiento de hipoteca.

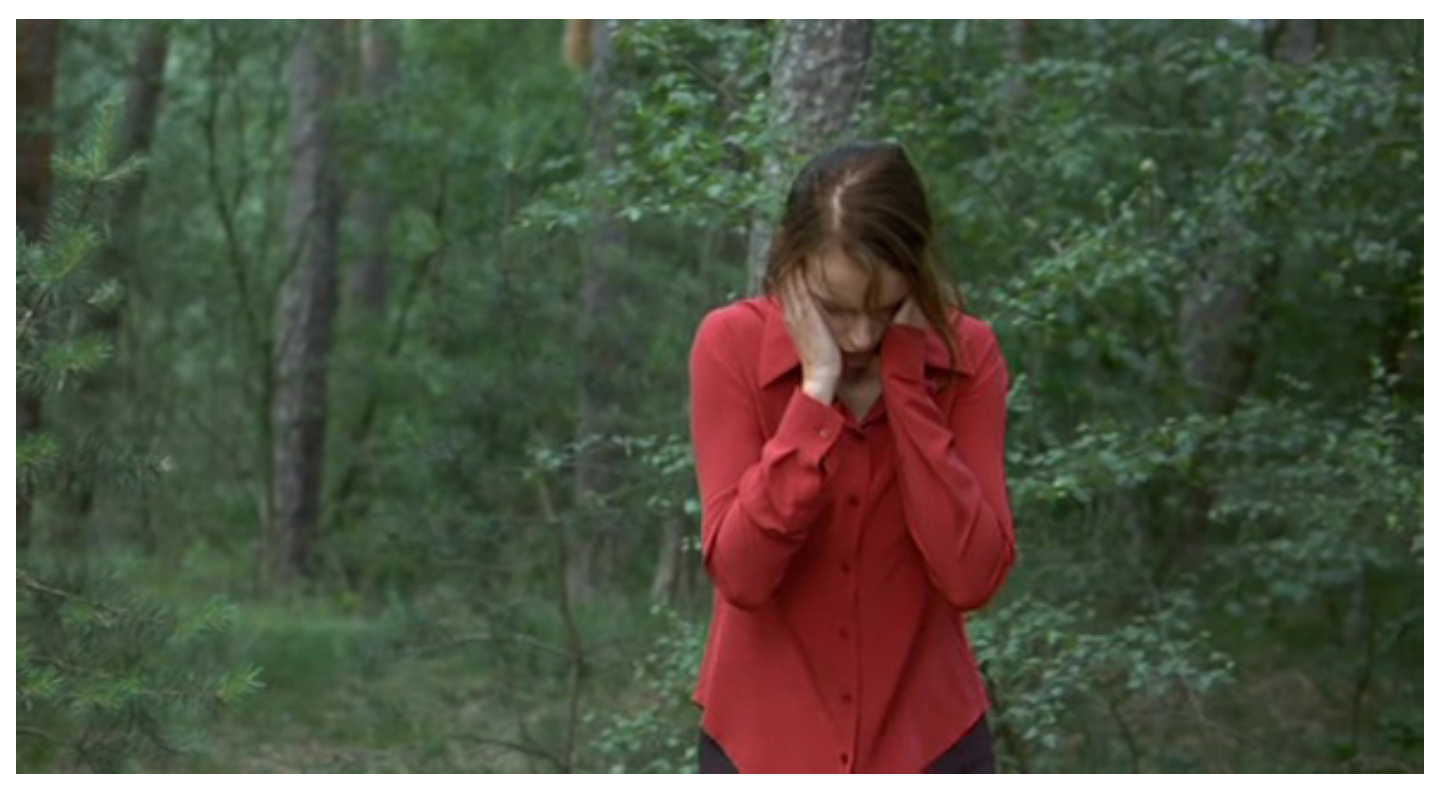

Fig. 5

Tanto en las entrevistas como en su obra hay referencias de Petzold al Angelus Novus de Klee, en versión de las Tesis sobre el concepto de la historia de Benjamin, o al cuadro de El Grito de Munch. Así ocurre en estos dos fotogramas de Yella (2007) [ figs. 4 y 5]. Desde el punto de vista cinematográfico la acuarela de Klee es un inmenso fuera de campo tanto espacial como temporal. El ángel, anclado en un presente, mira a un pasado que no vemos $\mathrm{y}$ es arrastrado a un futuro invisible pero no imprevisto. Aunque todos ellos determinan el presente y la acuarela pinta el cine como lo definiera Wenders en la primera nueva ola alemana: en el acto de ver. Es pura visión impotente, 
llena de buenas intenciones, a la vez que cómplice del desastre, ya que él procede del mismo lugar que el viento huracanado del Paraíso. Yella, como en el cuadro de Munch, se tapa los oídos, incapaz de aguantar ese zumbido interior que viene de la naturaleza y que la hace enloquecer.

Las películas de Petzold son del día después, de la caída del muro, de una crisis personal que se desconoce, del intento restaurador del ángel que no entiende nada, pero que sufre las consecuencias. Así en Phoenix (2014), donde el Holocausto es un fuera de campo del pasado que se quiere olvidar, no recordar ni remediar su injusticia pero que acaba determinando en el presente el futuro. No es que la ilustración haya devenido en barbarie sino que a esta le falta ilustración. Lo que aportan estas películas es conocimiento sobre esas vidas que sienten cómo se le escapa de las manos por obra de las circunstancias. Se ha apuntado la influencia en Yella de ideas como las vertidas por Marx en $\mathrm{El}$ 18 Brumario de Luis Bonaparte. Pero conviene precisar las citas. Esta: «Los hombres hacen su propia historia, pero no la hacen a su libre arbitrio, bajo circunstancias elegidas por ellos mismos, sino bajo aquellas circunstancias con que se encuentran directamente, que existen y les han sido legadas por el pasado. La tradición de todas las generaciones muertas oprime como una pesadilla el cerebro de los vivos», viene precedida por la cita inicial: «Hegel dice en alguna parte que todos los grandes hechos y personajes de la historia universal aparecen, como si dijéramos, dos veces. Pero se olvidó de agregar: una vez como tragedia y la otra como farsa».

El pasado de los muertos oprime como una pesadilla el cerebro de los vivos que llevan una existencia fantasmal. Así ocurre en la llamada «trilogía fantasma» de Petzold: Die innere Sicherheit, Gespenster, Yella. Pero especialmente en las películas sobre la Stasi y el Holocausto, Barbara y Phoenix. A la tesis de que los hombres no hacen su historia sino que se la hacen las circunstancias se añade el modo de representación, el cruce entre la tragedia y la farsa. Su resultado es un desvalimiento lírico de los personajes que impide tanto identificarlos como identificarse con ellos. La tragedia es lo que han dejado atrás, la farsa sus ansias de normalidad en el presente huyendo de las ruinas del pasado, una caricatura de perfil que se refleja en espejos rotos. La técnica que emplea Petzold, tomada de Farocki, de sus películas sobre publicidad, es lo que él denomina la técnica IKEA. Es la segunda mirada del nuevo realismo. Ya no se trata de un realismo que representa algo sino que lo transfigura, como los muebles vulgares y hasta feos de IKEA aparecen transfigurados en bellos por medio de la publicidad en los catálogos. Este es el proceder del romanticismo introduciendo lo misterioso en lo ordinario. Pero con diferencias importantes que impiden la sublimación y la identificación. El realismo de las sociedades complejas consiste en encontrar lo contradictorio en lo simple. En esa transfiguración de lo cotidiano en bellas imágenes no hay lugar a la sublimación, ya 
que se niega precisamente el elemento simbólico, compensatorio. Sus finales son el accidente que no cierra, las figuras de espaldas que vagan en el campo alejándose de él, sonámbulas, sin rumbo fijo. Es el resultado del día después de las tragedias en el presente anodino de la sociedad capitalista. Se mueven incesantemente, pero no viajan, ni tampoco se encuentran al término del mismo. Lo que queda es una geometría espacial del cuerpo con pocos diálogos que expresan la contradicción de ser producto de las circunstancias en una movilidad permanente. La poética de la imagen documenta esos procesos de movilidad en el sentido de metamorfosis sin cambios reales y sin ruptura, en un eterno retorno.

Con esta metodología y esos antecedentes se entiende el planteamiento de la «trilogía fantasma» de Petzold y su particular revisión del pasado alemán que aparece en las últimas películas. Así en Die innere Sicherheit (2001), coescrita con Farocki, en la que trata sobre los problemas psicológicos y familiares de antiguos terroristas de izquierda todavía perseguidos por la policía. Ya no atentan contra el sistema sino que intentan desesperadamente encontrar un hueco en él. No hay flashbacks, ni discursos en los que se ponga al espectador en antecedentes sobre sus actos pasados, por no haber no hay ni siquiera una mención explícita a aquellas actividades de las que informan vagamente en las sinopsis publicitarias de la película.

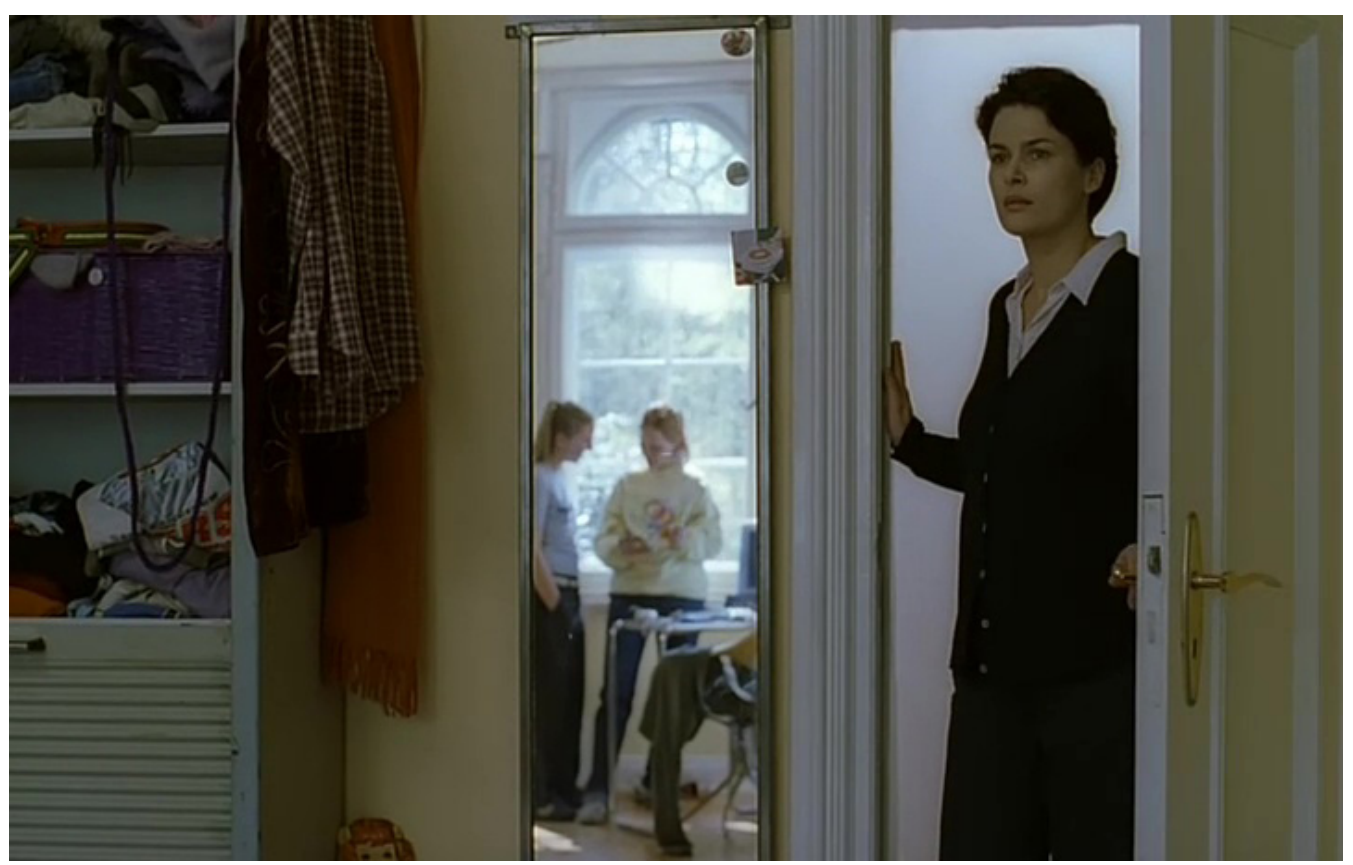

Fig. 6 
El pasado pesa más cuando no pasa en el cine, cuando no está pasando. Como en un cuadro de Vermeer, los espejos, los pasillos hacen de pantallas en las que se contemplan acciones, alguna de las cuales no ve directamente el espectador, solo su reflejo, que no es un recuerdo [fig. 6]. Lo de antes no es convocado, porque no se muestran causas, solo consecuencias sin ellas. La memoria no cuenta; solo el presente. Hay día después sin día anterior, pero este acecha invisible desde los límites de la pantalla, actuando en el miedo sin dejarse ver. Se oyen las sirenas de la policía, se esconden, pero no es a ellos a quienes buscan, sino a unos emigrantes. La película está llena de gestos contenidos, a diferencia del cine de carácter aquí se trata de gestos sin gesticulación. No es el pasado que pende sino el presente que suspende, eso que mantiene en vilo al espectador, con los viajes interminables en coche, pero sin la épica de la road movie. De cuando el presente no convoca, sino que es la elipsis de la historia. Ponen una película en la que aparecen restos de los hornos crematorios de los nazis, junto a los comentarios edificantes al uso, y el profesor se queja de que el interés de los estudiantes, el motivo de su asistencia, no es el contenido sino que se trataba de una «película», mientras que no aparecían en otras clases de historia que implicaran oír o leer algo. La diferencia aquí con otras películas en las que se aborda el tema del Holocausto es la indiferencia con la que se recibe, no exenta de una cierta curiosidad. Si acuden más en esta ocasión a la clase de Historia es porque ponen una película que es más entretenida (sea lo que sea) que la clase habitual.

Ellos, los antiguos terroristas y ahora meros supervivientes, solo quieren ser una familia normal, con los problemas habituales de una hija adolescente. La seguridad mencionada en el título de la película es el lado humano y frágil de lo monstruoso que huye. El espectador se sobresalta también ante el mínimo ruido, permanece atento sin saber por qué, levanta las manos rindiéndose ante una amenaza supuesta, respira aliviado cuando se desvanece, hasta la próxima. Al espectador tradicional no se le deja en paz, se le marea con este doble juego de cercanía y de distancia, naciendo un nuevo interés que no es fruto de la catarsis. Es el interés por el naufragio, ese momento de la película que reproduce la edición no recortada de Moby Dick: están en el agua, a la deriva, todo perdido, como Jeanne al final errando por el campo después del accidente, como las otras mujeres de los finales en las películas de Petzold.

A la ya citada de Yella, se une la más expresiva en el título, Gespenster (2005), fantasmas. La tragedia del fantasma es la de un estar sin ser. El estar supone un cuerpo sumamente expresivo sin gesticulación, sin casi palabras. El rostro es la ontología, pero el estar es el cuerpo. Con el primero la cámara se planta fija; con el segundo lo sigue, no se queda extática, sino que está en movimiento continuo. No para el tiempo, sino que va con él. De este modo en el estar hay una prevalencia del intervalo. La cámara no se detiene, ya que 
sigue de manera respetuosa a los personajes, se demora un punto en los objetos cuando aquellos han desaparecido [fig. 7]. Ya no se puede hablar de viaje, sino de trayectos, esta es la palabra clave. El trayecto no consiste en ir de un lugar a otro (con frecuencia quedan abiertos), sino de estar entre un lugar u otro. Ese quedarse atrapado es lo que define al fantasma como caricatura del ser humano que aspira también a construir lugares y estancias donde habitar. Esto hace también que la palabra sentido cambie de sentido. Ya no se trata de la orientación o desorientación en referencia tanto a lo lineal como a lo circular. No son «post», sino que están entre los diversos géneros, lo que significa que «circulan». Una palabra propia de la regulación del tráfico es la que tiene aplicación aquí. No se trata de que se detengan a mirar (¡circulen, circulen!) sino de que se vayan de allí, que no se estén quietos. Lo que se pone en cuestión con este tipo de procedimiento cinematográfico es el principio de la teleología, de la finalidad como principio de sentido. Frente a la «calle de dirección única», aquí se trata de las calles de la ambigüedad.

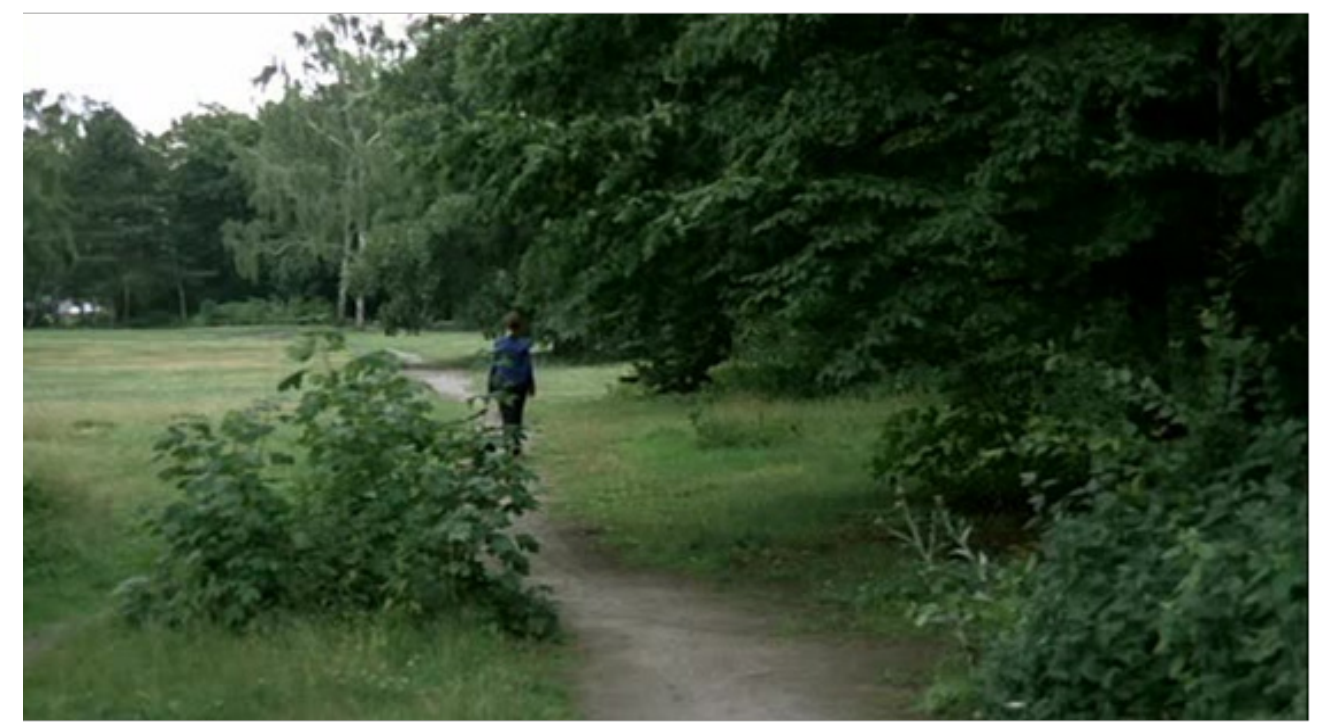

Fig. 7

Cuando la cámara enfoca al cuerpo se siente la situación, pero no porque tenga un sentido conceptual. La diferencia entre este planteamiento estético y el conceptual de la imagen (como el benjaminiano del Angelus Novus) es que no esquematiza, no se detiene. Por ello cuando hablan de la imagen, del arte, como tiempo detenido, en realidad se trata de la conceptualización del arte entendido ya solo como arte del concepto, cuando ya no expresamente buscado como arte conceptual. Por el contrario, en el minuto 5 de película lo único que hay es una escena secuencia de sucesión. Es precisamente ese elemento puramente 
cinético lo que llama la atención. Lo que caracteriza a estas películas es la vida en paralelo, en forma de historias no paralelas, sino simultáneas, pero cada una de ellas con final propio. De una forma u otra son seres heridos y desvalidos pero que esperan algo, tienen algunas alegrías, pequeñas esperanzas. Cuando Nina tira las fotografías de la niña muerta a la papelera lo hace con el fatalismo de que la esperanza no se ha cumplido: tener una madre, Françoise, tener una amiga, Toni. Se aleja, como el resto de los personajes femeninos de Petzold, de espaldas, recontándose su perfil en vacío del futuro.

En 2014 se estrena la película Phoenix, coescrita por Farocki con Petzold y dirigida por este último. A diferencia de otras películas sobre el Holocausto, Petzold sitúa a Phoenix en la órbita de lo que sí pretendía Farocki, no desde la perspectiva de 1969 (Fuego inextinguible), sino de 2014: «si yo les muestro ahora - decía allí Farocki- una víctima de la guerra de Vietnam abrasada por el napalm lo único que hacen es indignarse», «pero - añade Petzold- de lo que se trata es de ver la causa y el efecto y no solo la víctima. Esto es justo lo que hacen los alemanes consigo mismos, que se representan como víctimas, y de este modo se sustraen a cualquier reflexión y culpa».

En este tratamiento de las imágenes se rechaza explícitamente su uso como elementos de indignación en favor del conocimiento que proporcionan, de manipulación emocional frente a la posibilidad de aprender de ellas. Este enfoque de conocimiento y exactitud choca con otros moralistas e interesados en «ilustrar», es decir, demostrar una tesis. La película plantea el después de Auschwitz con un enfoque muy distinto del habitual: deseo de olvido, que se interpreta como perdón. Un paréntesis. La superviviente del campo regresa a Berlín con el rostro desfigurado, le ofrecen uno nuevo, pero ella quiere que sea igual que el antiguo. Si ha logrado sobrevivir ha sido por una palabra central en las películas de Petzold: amor. Es lo que la impidió sucumbir, el amor a su marido, el deseo de volver y estar con él. No quiere venganza, ni una nueva vida en Palestina como judía con los judíos, sino que todo vuelva a ser como antes. Los hematomas de la cara van desapareciendo en medio de su silencio y obstinación, de aceptar a parecerse a la de antes para un marido que no la identifica pero que la utiliza para heredarla, como antes quizá la traicionó.

Niega su «identidad»: «no soy judía», a lo que contesta su amiga que lo es quiera o no, y que por eso intentaron matarla. Su marido no la reconoce y en las ruinas de un Berlín devastado busca encontrarse en los fragmentos de los espejos del pasado [fig. 8]. La película es una investigación sobre el espejismo de la identidad que finaliza en otra sobre la identidad del espejismo. La amiga le advierte una y otra vez sobre este último y su suicidio es el último toque de atención sobre la inexistencia de ese amor al que ella se aferra. A diferencia de otras películas pedagógicas, directas, con voz en off e imágenes simbólicas, aquí lo dicen todo ellas mismas dialogando, no con toda una tradición, no haciendo 
teoría, sino cine sobre la pervivencia del nazismo después de Auschwitz. El pasado negro se traduce ahora en las imágenes del presente oscuro. La tradición del cine negro se hace presente en las sombras que andan apresuradas por las calles en la noche. Sombras como fantasmas, esa figura del espejismo de la identidad, recurrente en las películas de Petzold, y en contraste con los tubos de neón del cabaret. Toda la película es el intento desesperado y desvalido de Nelly de parecerse a quien Johnny quiere ahora y no quiso entonces. En realidad lo que ella piensa y desea, como el ángel benjaminiano, es que se puede cambiar (mejor poner entre paréntesis) el pasado si se puede realizar el presente como si nada hubiera ocurrido, como si el pasado no hubiera pasado. Esto no es posible y al filmarlo así Petzold está enlazando con el otro cine alemán, construyendo una tradición.

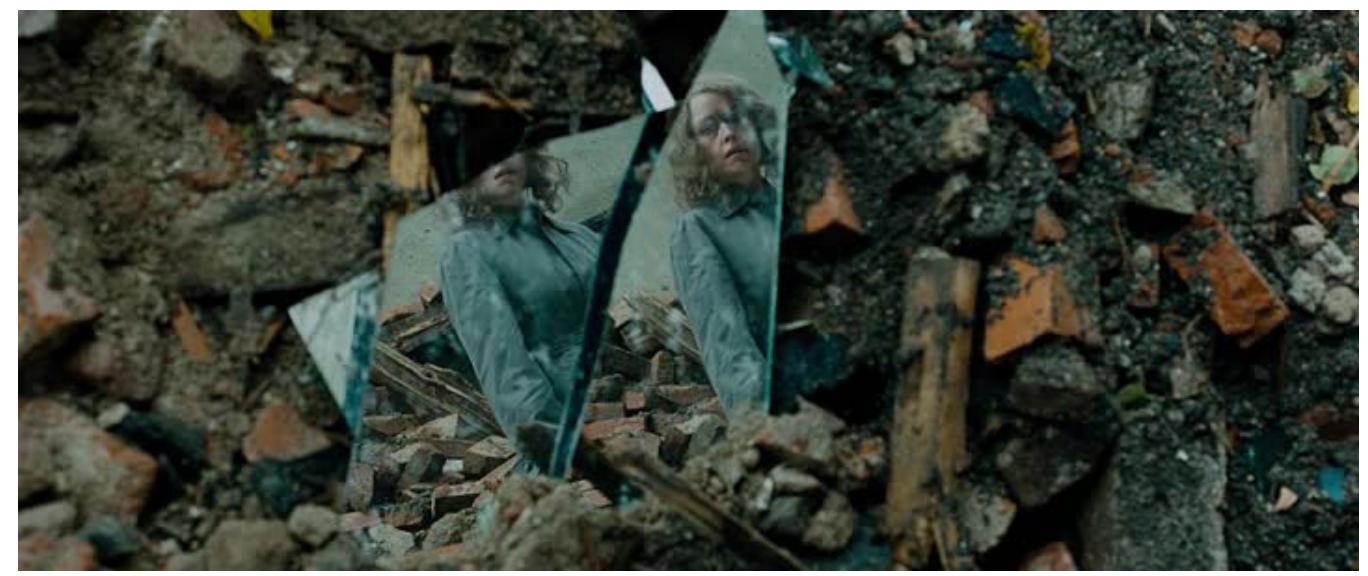

Fig. 8

La posiblemente mejor película de la posguerra alemana es El perdido y el propio Petzold la sitúa como antecedente de Phoenix. Su momento de estreno no fue el mejor, 1951, coincidiendo con el llamado «milagro económico alemán», cuando no se querían películas que miraran al pasado sino al futuro. Después de un corta exhibición desapareció de la cartelera y Lorre volvió a USA. Peter Lorre había sido el protagonista de la película de Brecht Mann ist Mann (1931), donde se puede apreciar la puesta en práctica del método del «extrañamiento» brechtiano.

Basada, como enfatiza la cartela, en acontecimientos reales, de ella cabe destacar sus extraordinarias imágenes, tanto los planos generales en que Lorre camina «perdido» como esos primeros planos en que, a veces alternativamente, otras en el mismo plano, aparece como verdugo y víctima, su doble identidad, como en M, el vampiro de Düsseldorf (1931). En un encuadre perfecto se muestra la silueta de «el perdido» y a la derecha su destino. El plano ha recogido 
el momento equidistante de ambos que se irán acercando conforme avance la secuencia [figs. 9 y 10].

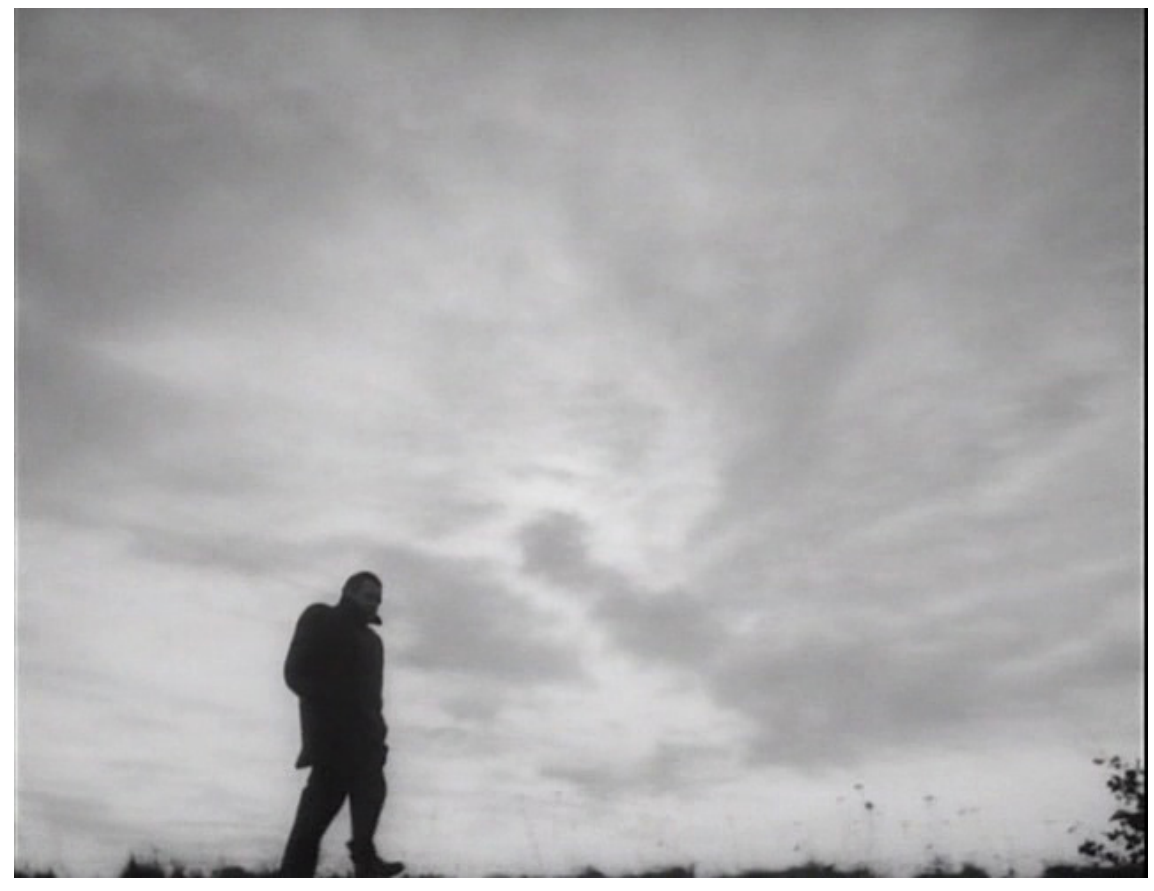

Fig. 9

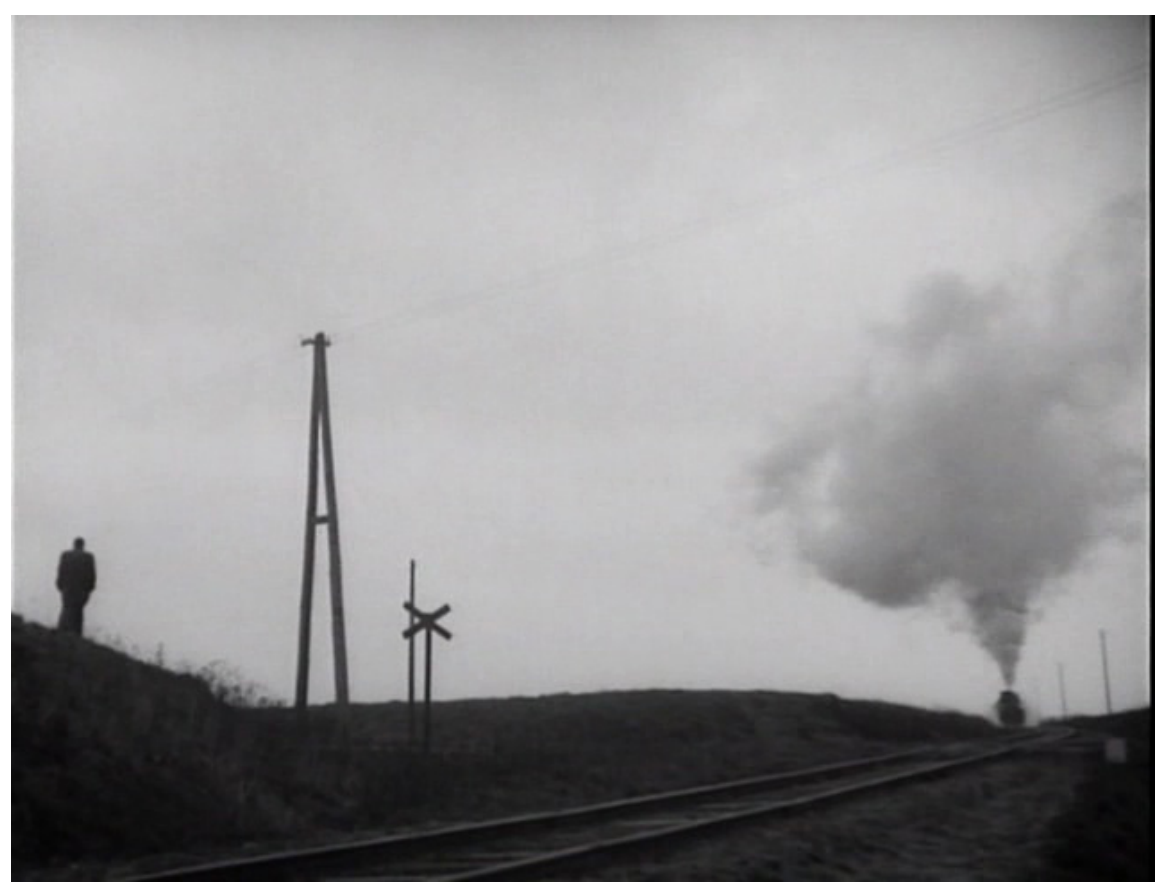

Fig. 10

Contrastes vol. XXI-N³ (2016) 
Aunque impone por su fuerza y velocidad la silueta creciente y amenazadora del tren, sin embargo los hilos casi invisibles de los postes que cruzan en diagonal la pantalla llevan a la mancha oscura que, tratándose de la silueta de un ser humano, la mirada biológicamente entrenada para ello no le quita ojo. Este plano general genera a la vez una distancia visual y una inmersión emocional. Tiene las características de lo sublime oscuro: amenaza por la derecha al ser humano que lo contempla a la izquierda, figura empequeñecida por la relación con el cielo, primero, y luego el humo y la mole de la máquina que pasa por las vías sin saber si ha acabado por pasarle por encima. El elemento soledad no se da solamente en esos momentos en que la cámara le sigue, sino también cuando está en el dispensario escuchando distraído a la gente, amable con desgana, como si viniera de otro lugar, perteneciera a otro sitio. La acción transcurre entre 1943 y 1945. Una identidad antes y otra después, pero la misma persona.

Es un doctor, que salva y, al mismo tiempo, un «Totmacher», como le llama la prostituta, un fabricante, hacedor de muerte. Los primeros planos del rostro de Lorre, sin que hable, con una gestualidad mínima, parecen una máscara que súbitamente se anima. Durante ese largo espacio de tiempo en que no dice, hace, nada, solo fuma y se mueve incesante, pero lentamente, se acentúa su carácter de in-decisión. No se sabe lo que va a hacer y cuando se supone que ha hecho algo queda velado por un fundido en negro. Es puro lenguaje corporal y la cámara se demora, no solo en el rostro sino en esa mano que recorre indecisa el borde de la consola. Sea cual sea el escenario da la impresión de que siempre se está dentro de un teatro y actuando como tal. Alguien entra, comienza a hacer cosas y se sobresalta cuando el foco ilumina parcialmente a un Lorre que sale de las sombras sin moverse encendiendo con sonrisa de medio lado el sempiterno cigarrillo. Usa las técnicas del cine negro americano que conoce muy bien, especialmente el contraste de luz y sombras. El conjunto de la figura y el rostro es el del hombre insignificante pero a los ojos de batracio asoma un horror que le posee. Es el mismo que viene de $M$ : «no había querido hacerlo pero lo hice y ahora vagaba en la noche ciego y sordo, perdido».

La alternancia de los flashbacks con el presente plantea desde el recuerdo el tema del olvido y desde la muerte la identidad entre verdugo y víctima. Desde la ambigüedad del presente aflora la del pasado tiñéndolo todo. Mezcla los crímenes que cometió antes inintencionadamente con el que comete ahora intencionadamente. Olvidó su culpabilidad por la falta de intención y ahora reconoce que «no se puede olvidar, simplemente no se puede». La imposibilidad de mantener el engaño para sí mismo es lo que le lleva a la decisión final. Pero el tema queda ahí planteado a la altura de 2014, ese mecanismo de compensación (opina Petzold) por el que los alemanes se declararon como víctimas de la fuerza del destino, de la fatalidad. Es el reino de las sombras que pueden ser de un superviviente o de un depredador, como en El tercer hombre. 


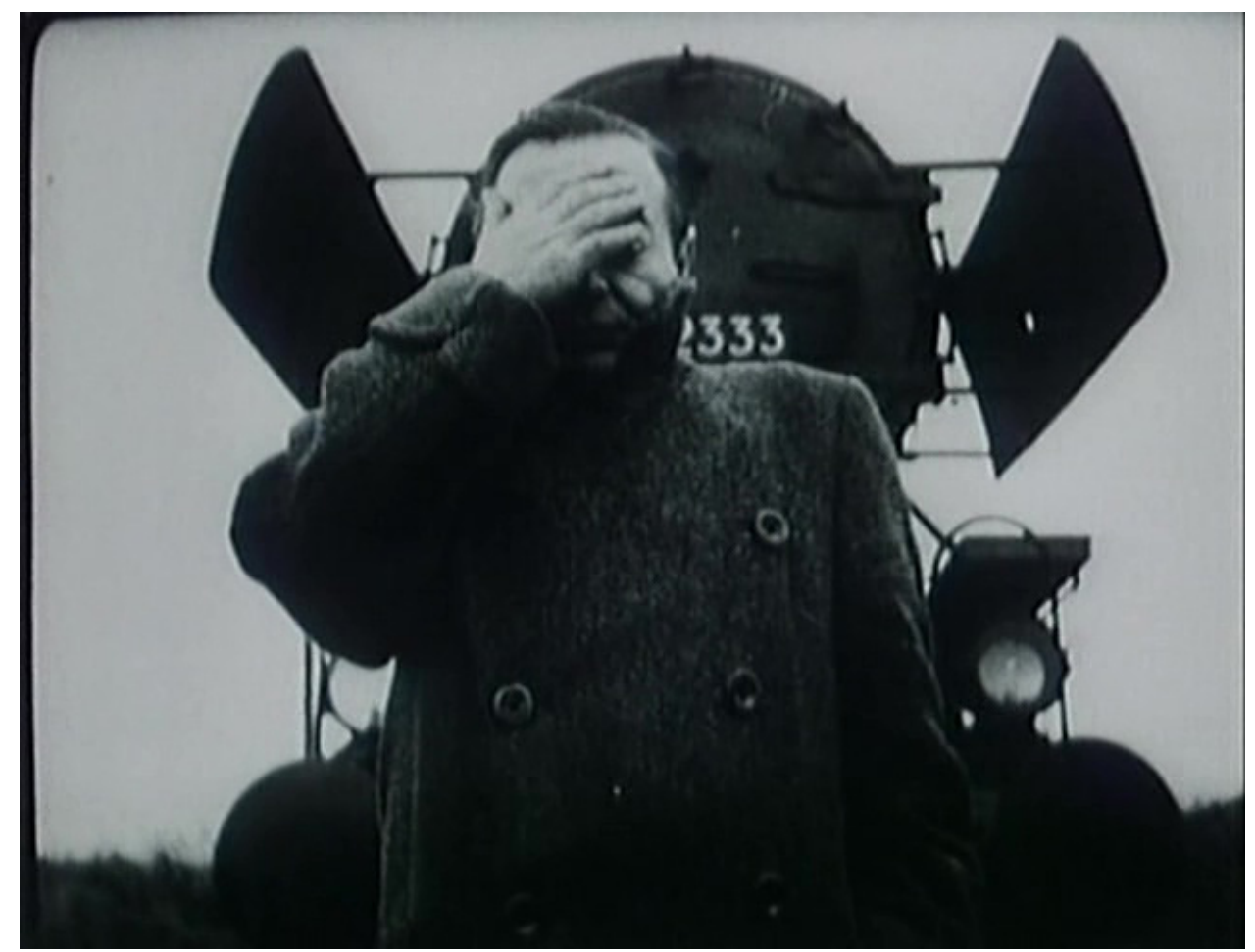

Fig. 11

Los problemas no se presentan solo cuando la ficción juega con la historia, sino cuando en la pantalla aparecen hermosas imágenes, no tan sofisticadas como para ser bellas, pero tampoco al puro servicio de la palabra. No son imágenes instrumentales, sino que se percibe el gusto por ellas mismas; más que ilustración de una tesis, son signo de la calidez humana que la puebla. Quizá sea este punto el de la calidez humana el que parece provocar más rechazo en lo que debía ser la descripción esquemática de una sociedad gris, vigilada hasta la crueldad. Pero de lo gris es precisamente como surgen, al igual que de las ruinas, toda esa serie de matices que conforman la imagen de perfil que sugiere una sociedad compleja en la que un oleaje de emociones se expresa a través del cuerpo, ya que deben ser medidas las palabras. Así sucede en Barbara, coescrita con Farocki y dirigida por Petzold.

La película cuenta un argumento pero, más que oírlo en la pantalla, la cámara sigue a los personajes, en particular a ella, en los desplazamiento en bicicleta, mientras está sentada en un banco, con planos generales, actividad que se denomina en el nuevo cine «la cámara respetuosa». Ese seguimiento, que deviene tiempo lento respecto a la «acción», establece un contraste lleno de matices con las películas sobre la Stasi, claustrofóbicas, de vigilancia en coches y escuchas interminables en habitaciones cerradas. Pero los paisajes idílicos de fuerte componente romántico, con el viento que mueve los árboles, 
no pretenden ese tipo de inmersión en el espectador, sino que subrayan ese carácter de cruce, más que de estancia, en que se encuentra la protagonista. Desterrada en una ciudad de provincias, vigilado hasta su más mínimo movimiento, la mirada se vuelve recelosa, siempre atenta a ese otro "seguimiento» irrespetuoso y humillante. Exterior con apariencia de libertad en el paisaje, soledad, opresión interior por la conciencia de no estar nunca sola: «Aquí nadie puede ser feliz», exclama en uno de los raros momentos de expresión de sus sentimientos. Las imágenes, aunque sea un plano general, están llenas de matices en el conjunto del montaje de la película.

Conocemos al personaje, más que por lo que dice, habitual en el cine, por cómo se mueve, haga o no haga nada. De este modo, aunque sea frontal, hay una parte de él que no emerge como evidente [fig. 11]. Esto desconcierta, ya que siendo una película sobre la Stasi no tiene el carácter de oficina del mal que hay en otras. Junto a los detalles sórdidos de las exploraciones fisiológicas como castigo se constata el factor humano del oficial de policía que sufre por la enfermedad terminal de su mujer. Es ese lado humano el que desconcierta en este tipo de planteamientos que se salen del marco de la denuncia para entrar en el de la comprensión. Las imágenes finales de los rostros que esbozan una sonrisa en la luz de los ojos enlazan con el otro avatar de esos mismos actores encarnando los personajes de Phoenix. Este planteamiento de Barbara se entiende mejor en el contraste con La vida de los otros (2006) de Florian Henckel von Donnersmarck, también sobre la Stasi. No todo fue heroísmo ni todo fue crueldad. Las identidades conceptuales son distintas de las identidades en situación. El error en el análisis puede consistir en mezclar unas con otras. Un ejemplo extremo de las identidades en situación se aprecia en la película de Hirschbiegel Das Experiment (2001), en la que las fronteras movedizas entre verdugo y víctima se vuelven letales.

Al final de La vida de los otros no hay una reconciliación sino la descripción de existencias que se cruzan y luego siguen cada una su camino. En una sociedad ideológicamente en descomposición, como la de la RDA, lo que la mantiene todavía en pie es la trama de confidentes traidores, políticos aprovechados pero, sobre todo, funcionarios grises más que honestos. En cierto sentido La vida de los otros es una vuelta de tuerca del corazón de las distopías estilo 1984 con toda su ambigüedad en la pretendida crítica al totalitarismo. El protagonista, Dreyman, es un escritor favorito del régimen, protegido de Marta Honecker, y con una cierta dosis de rebeldía que no incomoda. No es tanto un motivo ideológico, sino el suicidio de su amigo, el sí vetado Jerska, lo que le lleva a comprometerse. La vigilancia, como comprueba el capitán de la StasiWiesler, no es tanto por motivos políticos como personales, de chantaje en medio de rivalidades amorosas. Es el factor humano, por tanto, no el ideológico, el que va a dar la vuelta a la situación. HGW XX/7 (nombre en clave de Wiesler) se va 
a convertir en el rostro del Gran (Hermano) Amigo anónimo, en el destinatario de la pieza musical que le regala Jerska a Dreyman, Sonata para un hombre bueno, título a su vez del libro que le dedicará: «es para mí», dirá fundiendo las dos identidades al final de la película, con un esbozo de sonrisa en la cara inexpresiva a lo largo del filme.

Efectivamente, quien se conmueve con esa música no puede ser malo, siente Wiesler cuando oye tocarla, él tampoco puede ser malo si se conmueve con las poesías de Brecht cuando las lee después de haber robado el libro, al estilo de Fahrenheit 451. El «no todo fue tan malo» queda como poso ambiguo. La película permite comprender una situación, el contexto no sabe cómo juzgarla ¿Qué significa un «hombre bueno» en esa situación? No hizo lo que debía hacer sino lo que tenía que hacer. En esa situación no hay héroes propiamente dichos, sino vidas dañadas en diferente medida. Este es un elemento común en el nuevo cine. No hay propiamente finales, sino que la cámara les acompaña un trecho y luego se va. El pasado pesa y el futuro es un presente cuyo hilo se pierde. El contexto es trágico, un régimen totalitario de terror, pero el texto no lo es; más bien gris: en situaciones extremas o se rompe, como el suicida, o se corrompe, como el número excesivo de confidentes de la Stasi. La tonalidad, como la de los edificios, no es colorida, sino gris. En esa zona parece más heroico el perder todo dentro de la Stasi que contra ella, una forma peculiar de estética de la resistencia del funcionario. Este no critica ni se moviliza contra el sistema, sino contra una injusticia de un miembro prominente del sistema en el que cree y al que sirve. La paradoja es que salva al individuo en un sistema en el que lo que menos cuenta es precisamente él. Supone otra lente, fijarse en individuos que luchan y han luchado quebrando a individuos en nombre de un ideal abstracto.

El título es intercambiable: ha actuado como un hombre bueno, pero ¿es un buen hombre? El enfoque es netamente existencialista, toma una decisión que le salva como individuo pero le condena socialmente. Es la contrafigura de Eichmann, la banalidad del bien. La trampa estética: ¿puede ser mala una persona que tiene esos sentimientos estéticos?, se pregunta el capitán Wiesler. Y ahí comienza el cambio de actitud respecto a Dreyman y su pareja, y también del espectador respecto a él cuando se hace eco, furtivamente, de esos sentimientos. Estamos en las fronteras del esteticismo ético y estético.

La trilogía de «fantasmas» y las dos últimas películas son solo una muestra más explícita de unas constantes que se observan a lo largo de la trayectoria de Petzold y que van depurándose desde sus comienzos. Desde su primera película (Pilotinnen, 1995) la imagen de perfil muestra y, a la vez, esconde una personalidad [fig. 12]. Estas películas sacan a la luz los fantasmas del capitalismo tardío en una Alemania postmuro. 


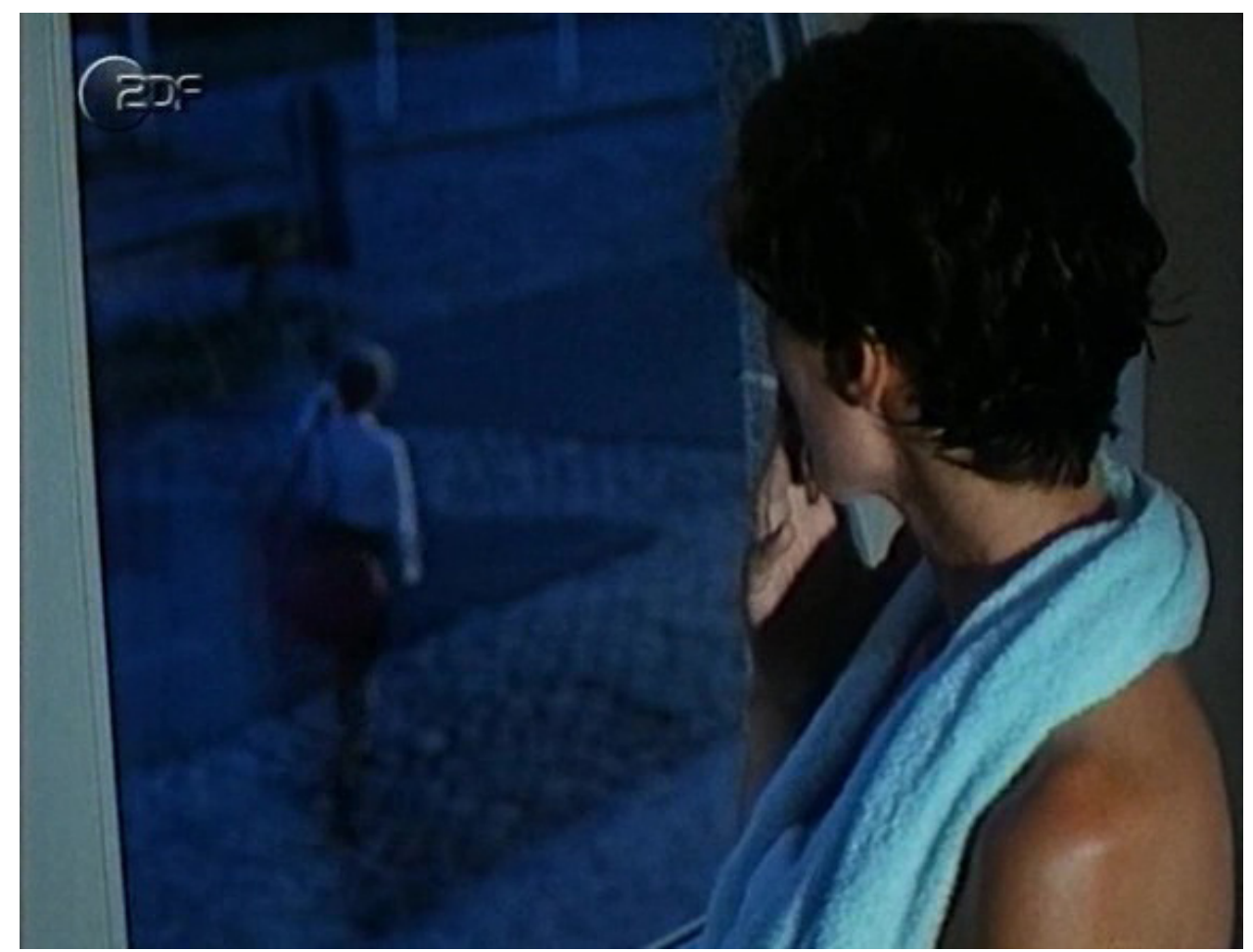

Fig. 12

Aplica técnicas del romanticismo luminoso alemán como el romantizar de Novalis, introduciendo lo misterioso en lo vulgar mediante la imagen bella, esa es la cara visible del perfil, pero también emplea las del romanticismo oscuro, resaltadas por el expresionismo de la doble identidad, la cara en sombra. El mundo exterior queda así a contraluz en esas historias sin historia. Las protagonistas femeninas no son nómadas, no hay nada de movilidad cosmopolita posmoderna. Es la otra cara (no Jameson) del capitalismo tardío, el modo como esas mujeres afrontan su pasado desde un presente movedizo con un futuro incierto, que se cierra. Lo que le interesa a Petzold es el fantasma de la identidad, no la identidad del fantasma: esa muñeca rusa que, conforme se va abriendo, no muestra a clones cada vez más pequeños, sino figuras contradictorias de lo mismo. Mientras que la narrativa fílmica habitual desarrolla cómo se construye o destruye una identidad, Petzold perfila los vacíos del fuera de campo en la persona, el hacer como consecuencia de una vida que le hacen, la causalidad en forma de casualidad. Son también (él y ella, ellas) personajes binarios que según la canción Moon River interpretada por Frank Sinatra en la película mencionada: "Los dos buscamos el mismo arco iris / que nos aguarda al final de la curva». Pero los personajes de Petzold no suelen tener el final feliz de los de los desvalidos en las películas de Aki Kaurismaki. Hasta puede que se cumplan sus deseos como en Jerichow (2008), en el que el 
cartero no llama dos veces, pero eso no es garantía de felicidad. Tampoco se puede reparar el pasado, aunque hay sido consecuencia de un accidente, como en Wolfsburg (2003).

En Toter Mann (2001) se «lee» que cada vida merece una segunda oportunidad. Los personajes de las películas de Petzold la buscan, pero ahí, en la lectura del libro, encuentran que su vida ya estaba escrita y lo que les sucede, lo que hacen, lo que los deshace, forma parte de un guión. El refinado lirismo visual de Barbara y Phoenix ha explotado ya aquí hasta el extremo de parecer que incluso Blum (un monstruo de Frankenstein en inversión) tendrá también su oportunidad. Un espejismo. Pero es lo que se espera de esos personajes a los que Perzold envuelve con frecuencia en la atmósfera de Hopper: es el día después de los Halcones de la noche en Cuba libre (1996). Es el lado amable y bello de lo siniestro, del pasado alemán remoto y más reciente, de los desmontes del capitalismo urbano. Lo siniestro es lo que emerge del lado oculto del perfil en lo visible del mismo y, fundiendo a Schelling y Freud, es la irrupción de lo secreto en lo familiar e incluso entrañable. Todos tienen sus paraísos soñados, se llamen Bora Bora, Niza, París, Cuba, y morirán junto al mar, no en el del Sur sino en el Báltico, al lado de un bar de mala muerte que lleva el nombre de Cuba libre. El resultado es una gran melancolía por la inutilidad de tanto esfuerzo y un enorme cansancio que pide ya parar. Hay momentos en que los sueños solo piden sueño. La tragedia desemboca así en farsa.

José Luis Molinuevo es Catedrático de Estética y Teoría de las Artes en la Universidad de Salamanca. 
